ORIGINAL ARTICLE

\title{
Validation of the Polish version of the Collective Self-Esteem Scale
}

\author{
Róża Bazińska \\ University of Social Sciences and Humanities, Faculty in Sopot, Poland
}

\section{BACKGROUND}

The aim of this article is to present research on the validity and reliability of the Collective Self-Esteem Scale (CSES) for the Polish population. The CSES is a measure of individual differences in collective self-esteem, understood as the global evaluation of one's own social (collective) identity.

\section{PARTICIPANTS AND PROCEDURE}

Participants from two samples ( $n=466$ and $n=1,009)$ completed a paper-pencil set of questionnaires which contained the CSES and the Rosenberg Self-Esteem Scale (RSES), and subsets of participants completed scales related to a sense of belonging, well-being and psychological distress (anxiety and depression).

\section{RESULTS}

Like the original version, the Polish version of the CSES comprises 16 items which form the four dimensions of col- lective self-esteem: Public collective self-esteem, Private collective self-esteem, Membership esteem and Importance of Identity. The results confirm the four-factor structure of the Polish version of the CSES, support the whole Polish version of the CSES as well as its subscales, which represent satisfactory reliability and stability, and provide initial evidence of construct validity.

\section{CONCLUSIONS}

As the results of the study indicate, the Polish version of the CSES is a valid and reliable self-report measure for assessing the global self-esteem derived from membership of a group and has proved to be useful in the Polish context.

\section{KEY WORDS}

collective self; group membership; collective self-esteem; validation

CORResponding Author - Róża Bazińska, Ph.D., University of Social Sciences and Humanities, Faculty in Sopot, 16/20 Polna Str., 81-745 Sopot, Poland, e-mail: rbazinska@swps.edu.pl 


\section{BACKGROUND}

Membership of important, larger groups is the most important manifestation of human functioning as a social being. The psychological meaning of a sense of belonging to different social groups involves a sense of security and self-worth, emotional bonds, and a reduction in uncertainty (Baumeister \& Leary, 1995; Hogg, 2007; Hogg \& Williams, 2000). Moreover, membership of a social group is a source of social identity and enables an individual to answer the question of who I am (Tajfel, 1981; Baumeister, 1998). It also allows one to achieve a positive image of one's self, which may result not only from positive evaluation of individual characteristics attributed to $\mathrm{Me}$ (individual self), but also from positive evaluation of the groups to which one belongs (collective-self; Brewer \& Gardner, 1996; Luhtanen \& Crocker, 1992; Tajfel, 1981).

\section{PERSONAL AND COLLECTIVE SELF FROM SOCIAL IDENTITY APPROACH}

The idea of distinguishing between the individual self and the collective one draws on the social identity theory (SIT) assumption that one's social behaviour can be described on two, relatively independent, planes - the interpersonal and the intergroup one (Tajfel, 1981; Tajfel \& Turner, 1986). Interpersonal behaviour is regulated by one's individual identity it reflects one's own attributes and qualities which distinguish a person from the others. Intergroup behaviour, on the other hand, depends on one's social (collective) identity, which encapsulates those aspects of one's self-image which result from one's membership of social groups, the values of those groups and their emotional relevance to the subject (Tajfel, 1981). In Tajfel's view, dynamic behaviours change on a continuum from interpersonal to intergroup ones. At the intergroup extreme of the continuum, the influence of one's individual qualities and interpersonal relations is reduced or eliminated altogether, and one's behaviour is influenced more by the membership of a specific group or social category, which comes to the fore in a given context (cf. Turner \& Onorato, 1999; Turner \& Reynolds, 2001). Hence, in this context, intergroup comparisons, in which people's striving to achieve positive social identity plays a significant role, take on a functional relevance. This kind of identity is founded on one's inclusion within an in-group which is positively distinguished from a relevant out-group. This proposition is reflected in the Self-Categorization Theory (SCT) of John Turner, who reformulated Tajfel's idea of the continuum interpersonal-intergroup and assumed that the differences between individual and social identity can be viewed as different levels of self-categorization (Turner, Hogg, Oakes, Reicher, \& Wetherell, 1987; Turner \& Onorato, 1999). The defining categories of the subject's self differ in the range of their inclusiveness. The individual self is defined through the categorization 'me' versus 'not-me', and the concept is based on interpersonal, implicitly intragroup comparisons (Turner \& Onorato, 1999). The collective self, on the other hand, is defined in terms going beyond the individual, which encompass the properties of the group to which the individual belongs. Thus, different group memberships form the basis for different self-categorizations (different social identities), and the contextually salient group membership activates collective identity, which results in a shift towards the perception of the self as an interchangeable exemplar of some social category and away from the perception of the self as a unique person (Turner et al., 1987). In other words, one's own self is now perceived in accordance with the group stereotype, in which the attributes of one's own group distinguish it from the attributes of a relevant out-group. Moreover, the group's attributes, norms, values and objectives motivate and control one's behaviour, thus enhancing intragroup similarities. Consequently, in an intergroup context, one's behaviour becomes relatively independent of those qualities which define the subject's individual self (Turner \& Reynolds, 2001), and the relative dominance of a specific level of self-categorization in a given social context influences the degree to which the subject's behaviour reveals either his individual qualities (personal self) or collective similarities (collective self), i.e. qualities shared with members of his own group (Brewer \& Gardner, 1996; see also Sedikides \& Brewer, 2001).

\section{PERSONAL AND COLLECTIVE SELF-ESTEEM}

Following the social identity perspective (Tajfel \& Turner, 1986; Turner et al., 1987; see also Hornsey, 2008; Turner \& Reynolds, 2001), Luhtanen and Crocker (1992) proposed a model of collective self-esteem in which self-evaluation is based on one's group membership. The authors posit that the groups to which one belongs serve as a basis for self-definition (collective self) and, consequently, self-evaluation (Brewer \& Gardner, 1996; Luhtanen \& Crocker, 1992; see also Sedikides \& Brewer, 2001). In their perspective, collective self-esteem is defined as the feelings of self-worth one derives from one's group memberships, whereas personal self-esteem is defined as the feelings of self-worth obtained from one's personal characteristics.

In their research aimed at developing the Collective Self-Esteem Scale (CSES), Luhtanen and Crocker (1992) proposed a model of collective self-esteem comprising the four components of the global col- 
lective self-esteem: membership collective self-esteem, private collective self-esteem, public collective self-esteem and identity collective self-esteem. These four components form four correlated subscales of the CSES. The Membership subscale refers to evaluation of oneself as a member of one's social groups and assesses the most individualistic part of collective self-esteem; the Private subscale refers to evaluation of one's social groups as judged by the self; the Public subscale refers to the perceived evaluation of others; and the Identity subscale refers to the importance of one's memberships to the self-concept. Three of them (Membership, Private and Public) are based on the dimension of positive to negative evaluation or favourability - that of one's attitude toward one's group memberships. The fourth subscale - Identity - concerns the importance of one's group memberships (see also Ashmore, Deaux, \& McLaughlin-Volpe, 2004; Branscombe, Ellemers, Bal, \& Doosje, 1999). In their research aimed at the construction of the CSES model the authors were able to obtain high reliability indices of the whole scale and its subscales and to confirm the four-factor structure of the CSES. Furthermore, the authors' research results proved that collective self-esteem is a construct distinct from personal self-esteem, although the two types of self-esteem are intercorrelated. Like Tajfel (1981), Turner et al. (1987), Brewer and Gardner (1996) and other researchers (Pelham \& Swann, 1994), the authors of the CSES share the belief that the collective level of representation of the self is connected with other than personal sources of self-esteem. Personal self-esteem is defined as the evaluative aspect of the self-concept (Baumeister, 1998), and its source is related to personal beliefs about one's skills, abilities and social relationships (see Heatherton \& Wyland, 2003). However, the personal aspects of self-esteem offered only a partial view of individuals' self and self-evaluation. According to the authors of the scale (Crocker \& Luhtanen, 1990; Luhtanen \& Crocker, 1992), personal self-evaluation plays a regulatory role at the level of personal and interpersonal activity, while collective self-esteem operates in an intergroup context (see Brewer \& Gardner, 1996). In terms of the social identity theory, the role of personal and collective self and type of self-esteem depend on the changing social context (Turner \& Onorato, 1999) in accordance with the dynamic of changes on the continuum from interpersonal to intergroup behaviours (from personal to social identity). Following this reasoning, the 'collective' refers on the one hand to the source of that self-esteem - one's self-assessment as a member of certain groups (We Poles, we women) as compared with other groups (Those Germans, those men) - and, on the other hand, to the context in which that self-evaluation becomes psychologically relevant (Brewer \& Gardner, 1996; Turner \& Reynolds, 2001).
Although both types of self-esteem - collective and personal - are distinct, they are related, as both feed into the overall sense of worth (Luhtanen \& Crocker, 1992; Tajfel \& Turner, 1986). Furthermore, they perform a similar function of a buffer against a threat (Brewer \& Gardner, 1996), but collective self-esteem protects one's self-worth more from a threat to social (collective) identity than to the individual, while personal self-esteem protects one's self-worth more from a threat to personal identity (Luhtanen \& Crocker, 1992). As several studies have shown, high personal self-esteem constitutes a resource which can protect an individual from negative experiences (Brown, 2010; see Zeigler-Hill, 2013). For instance, the stress-buffering model proposes that high self-esteem enhances the coping resource and protects an individual from negative effects of stress (see Zeigler-Hill, 2013). In turn, earlier research into collective self-esteem focused primarily on intergroup processes, such as intergroup differences (Long \& Spears, 1998; Long, Spears, \& Manstead, 1994), ingroup bias (Aberson, 1999; Crocker \& Luhtanen, 1990; Foels, 2006), or out-group derogation (Brandscombe \& Wann, 1994), and in-group processes (Jetten, Branscombe, \& Spears, 2002). In the last couple of decades there has been a growing amount of research regarding the relationships between collective self-esteem, mental health and well-being. In line with Luhtanen and Crocker's assumption that collective self-esteem, like personal self-esteem, is associated with psychological adjustment, some evidence obtained from the study of ethnic groups, groups of immigrants, sexual minorities and other stigmatized groups confirmed the prediction (e.g., Glupta, Rogers-Sirin, Okazaki, Ryce, \& Sirin, 2014; Mokgalhe \& Schoeman, 1998; Sanchez \& Vilain, 2009). The findings of this research revealed that higher ethnic collective self-esteem was related to higher subjective well-being in a sample of Asian American college students (Bettencourt \& Dorr, 1997). Crocker, Luhtanen, Blaine, and Broadnax (1994) found that higher ethnic collective self-esteem was related to lower levels of depression among Asian Americans, and the relationship was stronger for Asian than for White or Black American students. Lam (2007) also found that higher ethnic collective self-esteem was related to lower levels of both depression and anxiety among Vietnamese American college students. Similarly, Zea, Reisen, and Poppen (1999) found that higher collective self-esteem among gay Latino men was associated with lower levels of depression. Furthermore, there is growing evidence to suggest that women's reactions to prejudice and perceived discrimination against their gender group can be moderated by gender-based collective self-esteem (Corning, 2002; Fischer \& Bolton Holtz, 2007). On the whole, the evidence indicated that individuals who value their collective identities (i.e. ethnic identity, gender identity) may experience more positive 
subjective well-being and mental health, and suggested that collective self-esteem can be considered as a psychological resource, especially when social identity is threatened (Berjot \& Gillet, 2011; Branscombe et al., 1999).

\section{THE PRESENT RESEARCH}

The aims of the present research were threefold: (1) validation of the factor structure of the Polish version of the CSES; (2) determination of reliability of the CSES and its subscales (3) initial evidence of construct validity of the CSES. In line with the original CSES, we expected to replicate the factor structure and good psychometric properties of the CSES. More specifically, we hypothesized (Hypothesis 1) that a four-factor solution of collective self-esteem with correlated latent factors would fit the data best and (Hypothesis 2) that the CSES and its four subscales would prove reliable. In terms of construct validity, we predicted (Hypothesis 3) that the CSES would show moderately positive correlations with personal self-esteem but not with narcissism. Because collective self-esteem, like personal self-esteem, may have implications for psychological adjustment (Luhtanen \& Crocker, 1992), we expected (Hypothesis 4) that the CSES (and its subscales) would show a negative correlation with psychological distress (depression and anxiety) and a positive correlation with well-being (life satisfaction). Based on conceptualization of the collective self as a distinct, from interpersonal, source of one's sense of belonging (Brewer \& Gardner, 1996; Luhtanen \& Crocker, 1992; Tajfel \& Turner, 1986), we predicted that collective self-esteem would show a negative correlation with loneliness.

\section{PARTICIPANTS AND PROCEDURE}

\section{PARTICIPANTS}

Sample 1. A total of 466 participants comprised students (231 female and 235 male) of different disciplines (e.g., law, computer science, economics) from two universities. The participants, aged 19 to 28 $(M=20.70, S D=1.62)$, completed a questionnaire packet including demographic information, the Rosenberg Self-Esteem Scale and the Collective Self-Esteem Scale. Some subsets of participants also completed the Narcissism Personality Inventory - NPI $(n=99)$ or State Trait Anxiety Inventory - STAI $(n=98)$ or Beck Depression Inventory - BDI $(n=72)$ or Revised Loneliness UCLA Scale - UCLA $(n=101)$ or Satisfaction with Life Scale - SWLS $(n=101)$. To evaluate the test-retest reliability, 46 participants ( 30 female) of the sample, ranging in age from 22 to 27, completed the Polish version of the CSES a second time, four weeks after the first administration. Participation was voluntary.

Sample 2. A total of 1009 participants (509 female and 500 male), comprising 716 students from different faculties (e.g., education, law, environmental engineering) of two universities, and employees $(n=393)$ working in a variety of organizations (e.g., teachers, lawyers, administrative staff, tradespeople) aged 19 to $64(M=25.30, S D=9.24)$, completed the Polish version of the Collective Self-Esteem Scale and the Rosenberg Self-Esteem Scale in random order. The study was conducted on a voluntary basis, with no remuneration for the participants.

\section{MEASURES}

Collective Self-Esteem (CSE). The Collective Self-Esteem Scale (Luhtanen \& Crocker, 1992) is a 16-item self-report measure that assesses the global level of self-esteem based on one's membership of social groups. The CSES is composed of four subscales, each subscale consisting of four questions. The Membership CSES subscale items assess individuals' judgments of how good or worthy they are as members of their social groups (e.g., "I am a worthy member of the social groups I belong to"). The Private CSE subscale assesses one's personal judgments about how good one's social groups are (e.g., "I feel good about the social groups I belong to"). The items on the Public CSE subscale indicate how highly an individual believes others respect and value his social groups (e.g., "In general, others respect the social groups that I am a member of"). Finally, the Identity CSE subscale reflects how important one's social group memberships are to one's self-concept (e.g., "The social groups I belong to are an important reflection of who I am"). Using a 7-point scale, participants indicate the degree to which they agree or disagree with the statements (1 - strongly disagree; 2 - disagree; 3 - somewhat disagree; 4 - neutral; 5 - somewhat agree; 6 - agree; and 7 - strongly agree).

Translation of the English CSES to Polish was performed using a back translation procedure involving two independent translators, both of whom have $\mathrm{PhDs}$ in psychology. The two translations were then compared, and no differences were found between them. This version was translated back into English by two bilingual psychologists. After comparing the back translation with the original inventory, several minor changes were made. Pilot data were collected using this form with a small sample of psychology students $(n=24)$. Following feedback, a few additional minor alterations were made, and the final form was used to collect the data.

Personal self-esteem. To measure personal self-esteem, the Polish adaptation (Dzwonkowska, Lachowicz-Tabaczek, \& Łaguna, 2008) of the Rosenberg 
Self-Esteem Scale (RSES, Rosenberg, 1965) was used. The scale comprised 10 items such as "I take a positive attitude toward myself". Participants indicate the extent to which they agree or disagree with each item on a 4-point scale that ranges from 1 (strongly agree) to 4 (strongly disagree). Appropriate items are reverse-scored and an overall score of self-esteem is calculated by summing up the responses across items. Higher scores indicate higher self-esteem. Cronbach's $\alpha$ in this study was .86 .

Narcissism. The validated Polish version of the Narcissistic Personality Inventory (NPI; Bazińska \& DratRuszczak, 2000; Raskin \& Hall, 1979) was used as a measure of narcissism. The NPI is the most widely studied self-reported measure of narcissism designed for the nonclinical population. The Polish version of the NPI consists of 34 items using a 5-point scale ranging from 1 - does not apply to me to 5 - applies to me. In the present study, the coefficient alpha reliability was .91.

Depression. The Beck Depression Inventory (BDI; Beck, Ward, Mendelson, \& Erbaugh, 1961) was used as a measure of depressive symptoms. Beck Depression Inventory is a widely used 21-item self-reported scale with higher scores indicating stronger depression. Answer options include four increasing levels of severity. Scores for each item range from 0 to 3 , the total score being the sum of all the responses. Cronbach's $\alpha$ in this study was .90 .

Trait anxiety. State-Trait Anxiety Inventory - the Trait version of the State-Trait Anxiety Inventory (STAI; Spielberger, Gorsuch, Lushene, Vagg, \& Jacobs, 1983, the Polish version Sosnowski \& Trześniewski, 1983) was used as a measure of the degree of stable susceptibility to frequently experiencing state anxiety. The Trait scale of the STAI is composed of 20 self-reported items using a 4-point scale ranging from 1 - almost never to 4 - almost always. Appropriate items are reverse-scored and the overall score is their sum, with higher scores indicating higher anxiety as a trait. In the present study, the STAI-T had a coefficient alpha reliability of .93 .

Satisfaction with life. The Satisfaction with Life Scale (SWLS; Diener, Emmons, Larsen, \& Griffin, 1985; Polish adaptation Juczyński, 2001) was used to assess overall satisfaction with life. SWLS is a 5-item measure for the self-assessment of global satisfaction with life using a 7-point scale (ranging from 1 - strongly disagree to 7 - strongly agree). An SWLS total score is formed by adding up the points for the 5 items. Scores range from 5 to 35 , with higher scores indicating higher satisfaction with life. Cronbach's $\alpha$ in this study was .80 .

Loneliness. Loneliness was measured using the revised UCLA Loneliness Scale (Russell, 1996). A 20-item scale designed to measure general feelings of loneliness and degree of satisfaction with one's social connections. Participants rate each item along a 4-point scale: 1 - I never feel this way; 2 - I rarely feel this way; 3 - I sometimes feel this way; 4 - I often feel this way. Appropriate items are reverse-scored and the overall score is their sum, with higher scores indicating higher loneliness. In the present study, the UCLA had a coefficient $\alpha$ reliability of 89 .

\section{DATA ANALYSES}

First, the factor structure of the Polish CSES was investigated using exploratory factor analyses in Sample 1. Next, the fit of the factor structure identified in Sample 1 was tested in Sample 2 by performing confirmatory factor analysis (CFA). The CFA was used by SPSS Amos 21, aimed at comparing the fit of the different factor models of collective self-esteem. Normality was assessed by examining skew and kurtosis values for each item. Absolute values of skew and kurtosis beyond 2 and 7, respectively, may imply lack of univariate normality (Curran, West, \& Finch, 1996). In our study, skew values ranged from -0.98 to 0.42 , while kurtosis ranged from -0.34 to 1.27 . Because the data did not display any deviation from a normal distribution, the maximum likelihood (ML) estimation was employed. The CFA results were evaluated using the $\chi^{2}$ statistic and the ratio $\chi^{2} / \mathrm{df}$, which, if lower than 3, suggest an acceptable fit. However, because $\chi^{2}$ fit statistics are highly sensitive to sample size, several alternative goodness-of-fit statistics were used to assess the models ( $\mathrm{Hu} \&$ Bentler, 1999; Kline, 2005), including root mean square error of approximation (RMSEA), standardized root mean square residual (SRMR) and the comparative fit index (CFI). RMSEA values lower than .05 are usually considered good, while values lower than .08 are considered acceptable (Brown \& Cudeck, 1992). An SRMR value lower than .08 is generally considered a good fit. Finally, CFI values equal to or higher than .90 are considered acceptable, while values equal to or higher than .95 are considered good (Hu \& Bentler, 1999). The competing models (one-factor model, four-factor with uncorrelated factors, four-factor model with correlated factors, and four-factor hierarchical model) were compared by means of the $\chi^{2}$ difference test (Satorra \& Bentler, 2001). Internal consistencies of the subscales using Cronbach's $\alpha$ and test-retest reliability were investigated. Finally, construct validity of the scale was investigated using correlation analyses.

\section{RESULTS}

\section{FACTOR STRUCTURE OF THE POLISH VERSION OF THE CSES}

Exploratory factor analysis (Sample 1)

First, we assessed the factor structure of the CSES using exploratory factor analysis for Sample 1. 
A principal component analysis using all 16 items was performed. The Kaiser criterion and the scree plot indicated that four separate factors (explaining $55 \%$ of the total variance) should be extracted (four factors with eigenvalues $>1$, first five eigenvalues: $4.72,1.71,1.26,1.15$ and 0.97$)$. A promax rotation $(K=4)$ resulted in all the items loaded on the appropriate factors (four items in each factor), and all factor loadings ranged from .50 to .79 with only four cross-loadings above .40 (Table 1 shows the factor loadings). Given the results and relative high factor loadings of the items of the four subscales, we assumed that the four-factor solution of the Polish version of the CSES could be tested in further analysis according to the structure of the original CSES (Table 1).

\section{Confirmatory factor analysis (Sample 2)}

To further assess factorial validity, the CFA was performed using SPSS Amos 21.0. To test a hypothesized structure of the CSES, we compared the fit of the different factor models for the independent Sample 2.
Given findings from research of Luhtanen and Crocker (1992) and what was obtained in the EFA, we used the CFA to test the following models: (1) a one-factor model that loaded all CSES items onto a single latent factor, (2) four separate but uncorrelated factors and the final two models allowed the four factors to correlate, (3) a four-factor model where the factors are correlated on the first order, and (4) a hierarchical model where the four first-order factors are subsumed by a second-order general factor (Table 2).

The results of the CFA (see Table 2) indicate that the first model, loading all the CSES items onto a single latent factor, showed a poor fit to the data, as indicated by CFI, GFI and AGFI < .90, and RMSEA $>.08$. This provided evidence for multidimensional factor structure of the CSES. The second model, which specified four separate but uncorrelated factors, yielded poor fit indices with the RAMSES outside the accepted parameter of adequate fitting models and CFI, GFi and AGFI <.90. The four-correlated-factor model provided a better fit to the data than the four-factor uncorrelated model: $\Delta \chi^{2}(6)=544.39$,

Table 1

Factor loadings for the Polish version of the Collective Self-Esteem Scale, Sample $1(n=466)$

\begin{tabular}{|c|c|c|c|c|}
\hline \multirow[t]{2}{*}{ Subscale and Item } & \multicolumn{4}{|c|}{ Factor loading a } \\
\hline & $\mathrm{Me}$ & $\operatorname{Pr}$ & $\mathrm{Pu}$ & Id \\
\hline \multicolumn{5}{|l|}{ Membership } \\
\hline Me 1 & .620 & & & .452 \\
\hline Me 5 & .748 & & & \\
\hline Me 9 & .544 & .420 & & \\
\hline Me 13 & .777 & & & \\
\hline \multicolumn{5}{|l|}{ Private } \\
\hline $\operatorname{Pr} 2$ & & .782 & & \\
\hline $\operatorname{Pr} 6$ & .480 & .664 & & \\
\hline $\operatorname{Pr} 10$ & & .779 & & \\
\hline $\operatorname{Pr} 14$ & & .692 & & \\
\hline \multicolumn{5}{|l|}{ Public } \\
\hline $\mathrm{Pu} 3$ & & & .713 & \\
\hline $\mathrm{Pu} 7$ & & & .507 & \\
\hline Pu 11 & & & .716 & \\
\hline $\mathrm{Pu} 15$ & & & .525 & \\
\hline \multicolumn{5}{|l|}{ Identity } \\
\hline Id 4 & & & & .529 \\
\hline Id 8 & & & & .792 \\
\hline Id 12 & & & & .717 \\
\hline Id 16 & & .434 & & .783 \\
\hline
\end{tabular}

Note. Me - Membership subscale, Pr - Private subscale, Pu - Public subscale, Id - Identity subscale.

${ }^{a}$ Only factor loadings equal to or higher than .40 are indicated. 
Table 2

Goodness of fit indexes of four models of the Polish version of the Collective Self-Esteem Scale factor structure, Sample $2(n=1006)$

\begin{tabular}{cccccc}
\hline Model (ML estimation) & $\chi^{2} / d f$ & RMSEA & $\begin{array}{c}\text { RMSEA } \\
90 \% \mathrm{Cl}\end{array}$ & CFI & SRMR \\
\hline $\begin{array}{c}\text { Model 1. One-factor } \\
\text { Model 2. Four-factor } \\
\text { uncorrelated }\end{array}$ & $755.11 / 104$ & .079 & $.074-.084$ & .467 & .333 \\
$\begin{array}{c}\text { Model 3. Four-factor } \\
\text { correlated }\end{array}$ & $1042.28 / 104$ & .095 & $.089-.100$ & .817 & .322 \\
Model 4. Hierarchical & $534.00 / 103$ & .064 & $.059-.070$ & .916 & .105 \\
\hline
\end{tabular}

Note. RMSEA - root mean square error of approximation; CI - confidence interval; CFI - comparative fit index; SRMR - standardized root mean square residual. All $\chi^{2}$ statistics are significant at $p<.001$.

$p<.001$. All indices in the model were extended into the acceptable-fitting (CFI $>.90$, the RAMSEA $<.06$ and SRMR < .10). The final hierarchical model, where the four first-order factors are restricted to load equally on the second-order factor demonstrated an acceptable fit to data, including RMSEA $<.06$, SRMR $<.10$ and CFI $>.90$. This hierarchical model also represented a better fit to the data than the four-factor uncorrelated model: $\Delta \chi^{2}(1)=508.28, p<.001$. The results indicate that the four-factor and hierarchical models fit the data better than the other two models. The view of the superiority of these models was also held by Luhtanen and Crocker (1992) in their development of the CSES, where the four-correlated-factor and hierarchical models yielded acceptable values of fit indices.

\section{Descriptive statistics and reliability (Samples 1 and 2)}

Table 3 presents the means, standard deviations and Cronbach's $\alpha$ of the CSES and its subscales for two samples (Sample 1 and Sample 2; $N=1475$ ) combined. The Polish version of the CSES (i.e., total score) showed a mean of 80.60 and the means of the subscales ranged from 16.96 for Identity to 21.46 for
Private, 21.38 for Membership and 20.79 for Public subscales. Possible sex differences for the total score and subscale scores were investigated by conducting one-way analyses of variance with sex as the independent variable. The results showed that there were no significant differences between men and women for total and subscale scores of the Polish version of the CSES $\left(F_{\mathrm{S}}<1\right)$ (Table 3$)$.

Using Cronbach's $\alpha$ and test-retest correlation, reliability was assessed. As shown in Table 3, all subscales had good reliabilities. The items of the Polish CSES intercorrelated significantly, with a mean of .24 , and the total scale showed a substantial Cronbach's $\alpha$ of .84. The Cronbach's $\alpha$ coefficients for the Membership subscale were $\alpha=.75$ with a mean of .54 for the item-total correlation, $\alpha=.78$ for the Private subscale with a mean of .48 for the item-total correlation, $\alpha=.73$ for the Public subscale with a mean of .52 for the item-total correlation, and Identity subscale $\alpha=.76$ with a mean of .56 for the item-total correlation. Intercorrelations between subscales of the CSES are presented in Table 4. All correlations between the subscales were significantly positive and varied from .25 to .77 for Sample 1 and from .22 to .76 for Sample 2 .

Table 3

Descriptive statistics for the Polish version of the CSES and its subscales and their reliability for Sample 1 and Sample 2, combined

\begin{tabular}{ccccccc}
\hline Scale & Scale $M$ & Scale $S D$ & $\alpha$ & $\begin{array}{c}\text { Standard- } \\
\text { ized item } \alpha\end{array}$ & $\begin{array}{c}\text { Mean } \\
\text { inter-item } \\
\text { correlation }\end{array}$ & $\begin{array}{c}\text { Mean } \\
\text { item-total } \\
\text { correlation }\end{array}$ \\
\hline Sample 1 and Sample 2 combined $(N=1,455)$ & & & & & \\
Total CSES & 80.60 & 12.01 & .83 & .84 & .24 & .45 \\
Membership & 21.38 & 3.82 & .75 & .75 & .42 & .54 \\
Private & 21.46 & 4.19 & .78 & .79 & .48 & .59 \\
Public & 20.79 & 4.03 & .73 & .73 & .40 & .52 \\
Identity & 16.96 & 5.07 & .76 & .76 & .45 & .56 \\
\hline
\end{tabular}


Table 4

Polish version of the Collective Self-Esteem Subscales correlations

\begin{tabular}{|c|c|c|c|c|}
\hline Scale & Private & Public & Identity & Total \\
\hline \multicolumn{5}{|c|}{ Membership } \\
\hline Sample 1 & $.47^{* *}$ & $.45^{* *}$ & $.37^{* *}$ & $.77^{* *}$ \\
\hline Sample 2 & $.43^{* *}$ & $.34^{* *}$ & $.30^{* *}$ & $.66^{* *}$ \\
\hline \multicolumn{5}{|l|}{ Private } \\
\hline Sample 1 & & $.46^{* *}$ & $.33^{* *}$ & $.76^{* *}$ \\
\hline Sample 2 & & $.41^{* *}$ & $.31^{* *}$ & $.76^{* *}$ \\
\hline \multicolumn{5}{|l|}{ Public } \\
\hline Sample 1 & & & $.25^{* *}$ & $.71^{* *}$ \\
\hline Sample 2 & & & $.22^{* *}$ & $.68^{* *}$ \\
\hline \multicolumn{5}{|l|}{ Identity } \\
\hline Sample 1 & & & & $.70^{* *}$ \\
\hline Sample 2 & & & & $.68^{* *}$ \\
\hline
\end{tabular}

Note. There are four items in each subscale. Results from Sample $1(n=466)$ and Sample $2(n=1,009)$

${ }^{*} p<.01,{ }^{*} p<.001$.

The test-retest reliability on a subsample of 45 participants over 4 weeks was $.65(p<.001)$ for total CSES, $.70(p<.001)$ for the Membership subscale, .69 $(p<.001)$ for the Private subscale, $.77(p<.001)$ for the Public subscale and $.60(p<.001)$ for the Identity subscale. Overall, these results confirm the reliability of the Polish version of the CSES and its subscales.

\section{CONSTRUCT VALIDITY}

Validity assessments were conducted on subsamples of Sample 1 and Sample 2, on which the RSES, the NPI, the BDI, the STAI, the SWLS and the UCLA scales were also administered. Bivariate correlations between the Polish version of the CSES and its subscales and the established measures were used to test the sets of hypotheses on concurrent and discriminant validity, respectively (see Table 5).

First, in line with previous research (Luhtanen \& Crocker, 1992), we found supportive evidence for the concurrent validity of the CSES and personal self-esteem for Samples 1 and 2 combined. Table 4 shows that the overall scores of the CSES were significantly associated with Rosenberg Personal Self-Esteem, and all the subscales of the CSES, except for the Identity subscale, demonstrated moderate and positive correlations with personal self-esteem. The Membership subscale demonstrated the highest positive correlation with personal self-esteem. In terms of discriminant validity, the Membership subscale was moderately correlated with the NPI scores, while none of the other subscales was correlated with narcissism. Secondly, as seen in Table 5,

Table 5

Pearson correlations between the Polish version of the Collective Self-Esteem Scale and its subscales and other study variables for Samples 1 and 2

\begin{tabular}{ccccccc}
\hline Scale & $\begin{array}{c}\text { RSES } \\
(n=1475)\end{array}$ & $\begin{array}{c}\text { NPI } \\
(n=99)\end{array}$ & $\begin{array}{c}\text { STAI-T } \\
(n=98)\end{array}$ & $\begin{array}{c}\text { BDI } \\
(n=72)\end{array}$ & $\begin{array}{c}\text { SWLS } \\
(n=101)\end{array}$ & $\begin{array}{c}\text { UCLA } \\
(n=101)\end{array}$ \\
\hline Total CSES & $.36^{* *}$ & .20 & $-.32^{* *}$ & $-.26^{*}$ & $.34^{* *}$ & $-.45^{* *}$ \\
Membership & $.44^{* *}$ & $.33^{*}$ & $-.36^{* *}$ & $-.26^{*}$ & $.36^{* *}$ & $-.35^{* *}$ \\
Private & $.33^{* *}$ & .09 & $-.30^{* *}$ & $-.24^{*}$ & $.20^{*}$ & $-.48^{* *}$ \\
Public & $.23^{* *}$ & .10 & $-.28^{* *}$ & -.11 & $.20^{*}$ & $-.27^{* *}$ \\
Identity & .06 & .09 & -.05 & $-.25^{*}$ & $.25^{* *}$ & $-.21^{*}$ \\
\hline
\end{tabular}

Note. RSES - Rosenberg Self-Esteem Scale; NPI - Narcissism Personality Inventory; STAI-T - State Trait Anxiety Inventory - Trait Anxiety Subscale; BDI - Beck Depression Inventory; SWLS - Satisfaction with Life Scale; UCLA - Revised Loneliness UCLA Scale ${ }^{*} p<.05,{ }^{* *} p<.01$ 
the overall scores of the CSES were negatively correlated with the STAI-Trait scale and the BDI, as predicted. All subscales were moderately correlated with anxiety trait, and the Membership, Private and Public subscales were significantly correlated with the BDI, whereas the Identity subscale was not related to depression. Thirdly, the CSES and its subscales exhibited significant and moderate correlations with the SWLS in hypothesized directions, showing that collective self-esteem and its components are positively correlated with global life satisfaction. Finally, as predicted, all four components of collective self-esteem demonstrated negative correlations with the UCLA scale.

\section{DISCUSSION}

The present research evaluated the validity and reliability of the Polish version of the CSES. More exactly, the aims of the study obtained from two independent samples, which consisted of students and adults, were (1) to investigate the factor structure of the CSES, (2) to examine the reliability of the Polish version of the CSES and subscales, and (3) to test the construct validity of the CSES and its subscales.

The results confirmed the four-factor structure of the Polish CSES, indicating that collective self-esteem represents four relatively distinct dimensions, and, consistent with the findings of Luhtanen and Crocker (1992), the same four-factor structure was replicated within the two Polish samples, providing evidence of factor validity of the Polish CSES. Consistent with Luhtanen and Crocker (1992), the factor structure and intercorrelations of the four CSES subscales (moderate and low intercorrelations) findings provide evidence that Membership, Private, Public and Identity have a common core component (as a higher order factor). Moreover, the findings indicated that the Polish version of the CSES was highly reliable as total scores and as subscales of the CSES, both in terms of internal consistency of the Polish version of the CSES and its subscales and test-retest reliability over 4 weeks. Noteworthy is that all item-total correlations were above .45 . The results were comparable to results from Luhtanen and Crocker's (1992) research on the development of the CSES.

Although some different validity criteria than Luhtanen and Crocker (1992) were used, initial evidence for the construct validity of the scale was obtained. First of all, our correlation analysis results indicate that collective self-esteem is a concept related to but distinct from personal self-esteem. The Polish version of the CSES showed positive correlations with global personal self-esteem that were similar to those of the original CSES. As in Luhtanen and Crocker's research, the Membership, Personal and Public subscales correlated with personal self-esteem but Iden- tity was not related to personal self-esteem. In terms of discriminant validity, the Membership subscale had the highest correlation with personal self-esteem, which is consistent with the essence of the definition of this subscale as the most individualistic aspect of social identity (Luhtanen \& Crocker, 1992). Moreover, only the Membership subscale was related to narcissism, which is in line with the findings that high narcissism is related to both general agentic orientation (vs. communal orientation) and relative lack of interest in warm and caring interpersonal relationships (see Bazińska, Drat-Ruszczak, \& Pałucha, 2004; Campbell \& Foster, 2007; Drat-Ruszczak, Bazińska, \& Niemyjska, 2014). As predicted, the total scores of the CSES were negatively associated with measured overall psychological distress symptoms - depression and anxiety. More specifically, the Membership, Private and Identity subscales were negatively correlated with depression, and the Membership, Private and Public subscales were negatively related to trait anxiety. All subscales of the CSES were positively related to life satisfaction and showed negative correlations with loneliness. The results suggest that group membership and its impact on one's collective identity benefit individuals by meeting their need to feel socially connected to the social world (Lee \& Robins, 1995). In addition, we found support for the idea that collective self-esteem is related to one's sense of belonging, which then leads to improvement in an individual's mental health and well-being (Katz, Joiner, \& Kwon, 2002; Haslam, Jetten, Postmes, \& Haslam, 2009). Along similar lines, the correlation pattern between collective self-esteem and the indicators of psychological distress is in line with the rejection-identification model (Schmitt \& Brandscombe, 2002; see also Fischer \& Bolton Holz, 2010), which assumes that the shared social identity of members of disadvantaged groups provides individuals with the resources to cope with prejudice and discrimination against their groups.

\section{LIMITATIONS AND SUGGESTIONS FOR FUTURE RESEARCH}

Although two large samples with balanced gender composition and a relatively broad age range were used, the present study has some limitations. An important one of these is its correlation nature in term of the construct validity; therefore, it is not possible to draw any causal relationships among these variables. In addition, the Polish version of the CSES requires further investigation on the validity of the revised version of the CSES (i.e. CSES-R). The CSES-R was developed to measure collective self-esteem based on a particular group membership and had good psychometric properties in Luhtanen and Crocker's study (1992). Recently this version of the 
CSES has often been used in research of collective self-esteem based on particular group membership, and therefore future research is needed.

\section{CONCLUSIONS}

In conclusion, the current study presents evidence that the Polish version of the CSES is a reliable self-report measure for assessing the global self-esteem derived from group membership. A four dimensional model of collective self-esteem assessment in two large Polish samples was replicated in the research. Thus, the measure proved to be theoretically and empirically useful in the Polish context. It is also hoped that the present study will contribute to further research on the role of collective self-esteem in Polish social psychology.

\section{RefERENCES}

Aberson, C. (1999). Low a self-esteem and ingroup bias. Social Behavior and Personality, 27, 17-28.

Ashmore, R. D., Deaux, K., \& McLaughlin-Volpe, T. (2004). An organizing framework for collective identity: Articulation and significance of multidimensionality. Psychological Bulletin, 130, 80-114.

Baumeister, R. F. (1998). The self. In: D. Gilbert, S. T. Fiske, \& G. Lindzey (eds.), Handbook of social psychology (4 ${ }^{\text {th }}$ ed.) (pp. 680-740). Boston, MA: McGraw-Hill.

Baumeister, R. F., \& Leary, M. R. (1995). The need to belong: Desire for interpersonal attachments as a fundamental human motivation. Psychological Bulletin, 117, 497-529.

Bazińska, R., \& Drat-Ruszczak, K. (2000). Struktura narcyzmu w polskiej adaptacji kwestionariusza NPI Raskina i Halla [The structure of narcissism in the Polish adaptation of Raskin's and Hall's NPI questionnaire]. Czasopismo Psychologiczne, 6, 171-188.

Bazińska, R., Drat-Ruszczak, K., \& Pałucha, M. (2004). Preferowanie sprawności i ignorowanie moralności jako wyraz narcystycznej regulacji obrazu Ja [Preference of agency and ignoring morality as an expression of narcissistic self-image's regulation]. Czasopismo Psychologiczne, 2, 141-154.

Beck, A. T., Ward, C. H., Mendelson, M., Mock, J., \& Erbaugh, J. (1961). An inventory for measuring depression. Archives of General Psychiatry, 4, 53-63.

Berjot, S., \& Gillet, N. (2011). Stress and coping with stigmatization and discrimination. Frontiers in Educational Psychology, 2, 1-13.

Bettencourt, B. A., \& Dorr, N. (1997). Collective self-esteem as a mediator of the relationship between allocentrism and subjective well-being. Personality and Social Psychology Bulletin, 23, 955-964.
Blaine, B., \& Crocker, J. (1995). Religiousness, race, and psychological well-being: Exploring social psychological mediators. Personality and Social Psychology Bulletin, 21, 1031-1041.

Bollen, K. A. (1989). Structural equations with latent variables. New York, NY: John Wiley.

Branscombe, N. R., Ellemers, N., Bal, R., \& Doosje, B. (1999). The context and content of social identity threat. In: N. Ellemers, R. Spears, \& B. Doosje (eds.), Social identity: Context, commitment, and content (pp. 35-58). Oxford, UK: Blackwell.

Branscombe, N. R., \& Wann, D. L. (1994). Collective self-esteem consequences of out-group derogation when a valued social identity is on trial. European Journal of Social Psychology, 24, 641-657.

Brewer, M. B., \& Gardner, W. (1996). Who is this "we"? Levels of collective identity and self representations. Journal of Personality and Social Psychology, 71, 83-93.

Brown, J. D. (2010). High self-esteem buffers negative feedback: One more with feeling. Cognition and Emotion, 24, 1389-1404.

Brown, M. W., \& Cudeck, R. (1992). Alternative ways of assessing model fit. Sociological Methods and Research, 21, 230-258.

Campbell, W. K., \& Foster, J. D. (2007). The narcissistic self: Background, an extended agency model, and ongoing controversies. In: C. Sedikides, \& S. Spencer (eds.), Frontiers in Social Psychology: The Self (pp. 115-138). Philadelphia, PA: Psychology Press.

Campbell, W. K., Reeder, G. D., Sedikides, C., \& Elliot, A. J. (2000). Narcissism and comparative self-enhancement strategies. Journal of Research in Personality, 34, 329-347.

Corning, A. (2002). Self-Esteem as a moderator between perceived discrimination and psychological distress among women. Journal of Counseling Psychology, 49, 117-126.

Crocker, J., Luhtanen, R., Blaine, B., \& Broadnax, S. (1994). Collective self-esteem and psychological well-being among White, Black, and Asian college students. Personality and Social Psychology Bulletin, 20, 503-513.

Crocker, J., \& Luhtanen, R. (1990). Collective self-esteem and in-group bias. Journal of Personality and Social Psychology, 58, 60-67.

Crocker, J., Luhtanen, R., Blaine, B., \& Broadnax, S. (1994). Collective self-esteem and psychological well-being among White, Black, and Asiancollege students. Personality and Social Psychology Bulletin, 20, 503-513.

Curran, P. J., West, S. G., \& Finch, J. F. (1996). The robustness of test statistics to nonnormality and specification error in confirmatory factor analysis. Psychological Methods, 1, 16-29.

Diener, E., Emmons, R. A., Larsen, R. J., \& Griffin, S. (1985). The satisfaction with life scale. Journal of Personality Assessment, 49, 71-75. 
Drat-Ruszczak, K., Bazińska, R., \& Niemyjska, A. (2014). The mystery of communion in narcissism: The success-as-a-flaw effect. Polish Psychological Bulletin, 45, 453-463.

Dzwonkowska, I., Lachowicz-Tabaczek, K., \& Łaguna, M. (2008). Samoocena i jej pomiar. Polska adaptacja skali SES M. Rosenberga. Podręcznik [Self-esteem and its measurement. Polish adaptation of M. Rosenberg's SES. A manual]. Warszawa: Pracownia Testów Psychologicznych.

Fischer, A. R., \& Bolton Holz, K. (2007). Perceived discrimination and women's psychological distress: The roles of collective and personal self-esteem. Journal of Counseling Psychology, 54, 154-164.

Fischer, A. R., \& Bolton Holz, K. (2010). Testing a model of women's personal sense of justice, control, well-being, and distress in the context of sexist discrimination. Psychology of Women Quarterly, 34, 297-310.

Foels, R. (2006). In group favoritism and social self-esteem in minimal groups: changing a social categorization into a social identity. Current $R e$ search in Social Psychology, 12, 38-53.

Głupta, T., Rogers-Sirin, L., Okazaki, S., Ryce, P., \& Sirin, S. R. (2014). The role of collective self-esteem on anxious-depressed symptoms for Asian and Latino children of immigrants. Cultural Diversity and Ethnic Minority Psychology, 20, 220-230.

Haslam, A. S., Jetten, J., Postmes, T., \& Haslam, C. (2009). Social identity, health and well-being: An emerging agenda for applied psychology. Applied Psychology, 58, 1-23.

Heatherton, T. F., \& Wyland, C. L. (2003). Assessing self-esteem. In: Lopez S. J., \& Snyder, C. R. (eds.), Positive psychological assessment: $A$ handbook of models and measures (pp. 219-233). Washington, DC, US: American Psychological.

Hogg, M. A. (2007). Uncertainty-identity theory. Advances in Experimental Social Psychology, 39, 69-126.

Hogg, M. A., \& Williams, K. D. (2000). From I to we: Social identity and the collective self. Group $D y$ namics: Theory, Research, and Practice, 4, 81-97.

Hornsey, M. (2008). Social Identity Theory and Self-categorization Theory: A Historical Review. Social and Personality Psychology Compass, 2/1, 204-222.

Hu, L., \& Bentler, P. M. (1999). Cutoff criterion for fit indexes in covariance structure analysis: Conventional criteria versus new alternatives. Structural Equation Modeling, 6, 1-55.

Jetten, J., Branscombe, N. R., \& Spears, R. (2002). On being peripheral: Effects of identity insecurity on personal and collective self-esteem. European Journal of Social Psychology, 32, 105-123.

Juczyński, Z. (2001). Narzędzia pomiaru w promocji i psychologii zdrowia [Measures in promotion and health psychology]. Warszawa: Pracownia Testów Psychologicznych Polskiego Towarzystwa Psychologicznego.
Katz, J., Joiner Jr., T. E., \& Kwon, P. (2002). Membership in a devalued social group and emotional well-being: Developing a model of personal self-esteem, collective self-esteem, and group socialization. Sex Roles, 47, 419-431.

Kline, R. B. (2005). Principles and practice of structural equation modeling ( $2^{\text {nd }}$ ed.). New York: The Guilford Press.

Lam, B. T. (2007). Impact of perceived racial discrimination and collective self-esteem on psychological distress among Vietnamese-American college students: Sense of cohesion as mediator. American Journal of Orthopsychiatry, 77, 370-376.

Lee, R. M., \& Robbins, S. B. (1995). Measuring belongingness: The Social Connectedness and the Social Assurance Scales. Journal of Counseling Psychology, 42, 232-241.

Long, K. M., \& Spears, R. (1998). Opposing effects of personal and collective self-esteem on interpersonal and intergroup comparisons. European Journal of Social Psychology, 28, 913-930.

Long, K. M., Spears, R., \& Manstead, A. S. R. (1994). The influence of personal and collective self-esteem on strategies of social differentiation. British Journal of Social Psychology, 33, 313-329.

Luhtanen, R., \& Crocker, J. (1992). A collective self-esteem scale: self-evaluation of one's social identity. Personality and Social Psychology Bulletin, 18, 302-318.

Mokgalhe, B., \& Schoeman, J. (1998). Predictors of satisfaction with life: The role of racial identity, collective self-esteem, and gender-role attitudes. South African Journal of Psychology, 29, 28-35.

Pelham, B. W., \& Swann, W. B., Jr. (1994). The juncture of intrapersonal and interpersonal knowledge: Self-certainty and interpersonal congruence. Personality and Social Psychology Bulletin, 20, 349-357.

Rosenberg, M. (1965). Society and the adolescent self-image. Princeton, NJ: Princeton University Press.

Raskin, R., \& Hall, C. S. (1979). The Narcissistic Personality Inventory. Psychological Reports, 45, 159-162.

Russell, D. (1996). The UCLA Loneliness Scale (Version 3): Reliability, validity, and factor structure. Journal of Personality Assessment, 66, 20-40.

Satorra, A., \& Bentler, P. M. (2001). A scaled difference $\chi^{2}$ test statistic for moment structure analysis. Psychometrika, 66, 507-514.

Sanchez, F. J., \& Vilain, E. (2009). Collective self-esteem as a coping resource for Male-to-Female Transsexuals. Journal of Counseling Psychology, 56, 202-209.

Schmitt, M. T., \& Branscombe, N. R. (2002). The meaning and consequences of perceived discrimination in disadvantaged and privileged social groups. In: W. Stroebe, \& M. Hewstone (eds.), European Review of Social Psychology, 12, 167-199. Chichester, England: Wiley. 
Sedikides, C., \& Brewer, M. B. (2001). Individual self, relational self, collective self. New York, NY US: Psychology Press

Sosnowski, T., \& Wrześniewski K. (1983). Polska adaptacja inwentarza STAI do badania stanu i cechy lęku [Polish adaptation of the STAI for measurement of state and trait anxiety]. Przeglad Psychologiczny, 26, 393-412.

Spielberger, C. D., Gorsuch, R. L., \& Lushene, R. E. (1983). Manual for the State-Trait Anxiety Inventory. Consulting Psychologists Press, Inc.

Tajfel, H. (1981). Human groups and social categories: Studies in social psychology. Cambridge: Cambridge University Press.

Tajfel, H., \& Turner, J. C. (1986). The social identity theory of intergroup behavior. In: S. Worchel, \& W. G. Austin (eds.), The psychology of intergroup relations (pp. 7-24). Chicago: Nelson-Hall.

Turner, J. C., \& Onorato, R. S. (1999). Social identity, personality, and the self-concept: A self-categorization perspective. In: T. R. Tyler, R. Kramer, \& O. Johns (eds.), The psychology of the social self (pp. 11-46). Mahwah, NJ: Erlbaum.

Turner, J. C., \& Reynolds, K. J. (2001). The social identity perspective in intergroup relations: Theories, themes, and controversies. In: R. Brown, \& S. L. Gaertner (eds.), Blackwell handbook of social psychology: Intergroup processes (pp. 133-152). Oxford, UK: Blackwell.

Turner, J. C., Hogg, M. A., Oakes, P. J., Reicher, S. D., \& Wetherell, M. (1987). Rediscovering the social group: A self-categorization theory. Oxford, UK: Blackwell.

Zea, M. C., Reisen, C. A., \& Poppen, P. J. (1999). Psychological well-being among Latino lesbians and gay men. Cultural Diversity \& Ethnic Minority Psychology, 5, 371-379. DOI: 10.1037/10999809.5.4.371

Zeigler-Hill, V. (2013). The importance of self-esteem. In: V. Zeigler-Hill (ed.), Self-Esteem. London and New York: Psychology Press, Taylor \& Francis Group. 
APPENDIX

\section{Skala Zbiorowej Samooceny CSES}

Instrukcja: Wszyscy jesteśmy członkami różnych grup i kategorii społecznych. Niektóre z nich odnoszą się do płci, religii, narodowości, inne oznaczają grupy zawodowe, klasy społeczno-ekonomiczne lub też grupy opierające się na wspólnych zainteresowaniach czy poglądach. Chcielibyśmy, abyś rozważył(a) swoją przynależność do grup i szerszych kategorii społecznych, a następnie ustosunkował(a) się do poniższych stwierdzeń, na podstawie tego, jak czujesz się jako członek tych grup. Nie ma złych i dobrych odpowiedzi, ważne, aby były one zgodne z własnymi odczuciami.

Prosimy o przeczytanie poniższych stwierdzeń i ustosunkowanie się do nich za pomocą skali od 1 do 7.

\begin{tabular}{|c|c|c|c|c|c|c|c|c|c|c|c|c|}
\hline & 1 & 2 & 3 & 4 & 5 & & \multicolumn{3}{|c|}{6} & \multicolumn{3}{|c|}{7} \\
\hline \multicolumn{2}{|c|}{$\begin{array}{c}\text { Zdecydowa- } \\
\text { nie się nie } \\
\text { zgadzam }\end{array}$} & $\begin{array}{l}\text { Nie zgadzam } \\
\text { się }\end{array}$ & $\begin{array}{l}\text { Raczej się } \\
\text { nie zgadzam }\end{array}$ & $\begin{array}{l}\text { Trudno } \\
\text { powiedzieć }\end{array}$ & $\begin{array}{l}\text { Raczej sie } \\
\text { zgadzam }\end{array}$ & & Zgac & am & & & & \\
\hline 1 & \multicolumn{5}{|c|}{$\begin{array}{l}\text { Myślę, że jestem wartościowym członkiem grup, } \\
\text { do których należę. }\end{array}$} & 1 & 2 & 3 & 4 & 5 & 6 & 7 \\
\hline 2 & \multicolumn{5}{|c|}{ Często żałuję, że należę do niektórych grup społecznych. } & 1 & 2 & 3 & 4 & 5 & 6 & 7 \\
\hline 3 & \multicolumn{5}{|c|}{ Grupy, do których należę, ogólnie uważane są za wartościowe. } & 1 & 2 & 3 & 4 & 5 & 6 & 7 \\
\hline 4 & \multicolumn{5}{|c|}{$\begin{array}{l}\text { Grupy, których jestem członkiem, mają mały wpływ na to, } \\
\text { co myślę o sobie i kim jestem. }\end{array}$} & 1 & 2 & 3 & 4 & 5 & 6 & 7 \\
\hline 5 & \multicolumn{5}{|c|}{$\begin{array}{l}\text { Czuję, że nie mam zbyt dużo do zaoferowania tym grupom } \\
\text { społecznym, których jestem członkiem. }\end{array}$} & 1 & 2 & 3 & 4 & 5 & 6 & 7 \\
\hline 6 & \multicolumn{5}{|c|}{$\begin{array}{l}\text { Ogólnie jestem zadowolony(a) z przynależności do grup, których } \\
\text { jestem członkiem. }\end{array}$} & 1 & 2 & 3 & 4 & 5 & 6 & 7 \\
\hline 7 & \multicolumn{5}{|c|}{$\begin{array}{l}\text { Grupy, do których należę, w opinii większości są uważane } \\
\text { za mało skuteczne w porównaniu z innymi grupami. }\end{array}$} & 1 & 2 & 3 & 4 & 5 & 6 & 7 \\
\hline 8 & \multicolumn{5}{|c|}{ Grupy, do których należę, w dużej mierze określają to, kim jestem. } & 1 & 2 & 3 & 4 & 5 & 6 & 7 \\
\hline 9 & \multicolumn{5}{|c|}{ Myślę, że jestem pomocnym członkiem grup, do których należę. } & 1 & 2 & 3 & 4 & 5 & 6 & 7 \\
\hline 10 & \multicolumn{5}{|c|}{$\begin{array}{l}\text { Mam poczucie, że grupy, do których należę, nie są warte } \\
\text { mojego czasu. }\end{array}$} & 1 & 2 & 3 & 4 & 5 & 6 & 7 \\
\hline 11 & \multicolumn{5}{|c|}{$\begin{array}{l}\text { Inni ludzie odnoszą się z szacunkiem do grup, } \\
\text { których jestem członkiem. }\end{array}$} & 1 & 2 & 3 & 4 & 5 & 6 & 7 \\
\hline 12 & \multicolumn{5}{|c|}{$\begin{array}{l}\text { Grupy społeczne, do których należę, nie mają żadnego wpływu } \\
\text { na to, kim jestem. }\end{array}$} & 1 & 2 & 3 & 4 & 5 & 6 & 7 \\
\hline 13 & \multicolumn{5}{|c|}{$\begin{array}{l}\text { Mam poczucie, że jestem bezużytecznym członkiem grup, } \\
\text { do których należę. }\end{array}$} & 1 & 2 & 3 & 4 & 5 & 6 & 7 \\
\hline 14 & \multicolumn{5}{|c|}{$\begin{array}{l}\text { Dobrze się czuję jako członek grup społecznych, } \\
\text { do których należę. }\end{array}$} & 1 & 2 & 3 & 4 & 5 & 6 & 7 \\
\hline 15 & \multicolumn{5}{|c|}{$\begin{array}{l}\text { Powszechna opinia społeczna jest taka, że grupy, } \\
\text { do których należę, są nic niewarte. }\end{array}$} & 1 & 2 & 3 & 4 & 5 & 6 & 7 \\
\hline 16 & \multicolumn{5}{|c|}{$\begin{array}{l}\text { Ogólnie biorąc, moja przynależność do grup stanowi } \\
\text { ważną częścią mojego Ja. }\end{array}$} & 1 & 2 & 3 & 4 & 5 & 6 & 7 \\
\hline
\end{tabular}

\section{KLUCZ do CSES}

Pozycje do odwrócenia: $(1=7,2=6,3=5,4=4,5=3,6=2,7=1): 2,4,5,7,10,12,13,15$.

Ocena siebie jako członka grup (membership self-esteem) - suma pozycji: 1, 5, 9, 13.

Prywatna zbiorowa samoocena (private self-esteem) - suma pozycji: 2, 6, 10, 14.

Publiczna zbiorowa samoocena (public collective self-esteem) - suma pozycji: 3, 7, 11, 15.

Ważność tożsamości (importance to identity) - suma pozycji: 4, 8, 12, 16. 